\title{
New Technologies: The Good, the Bad, and the Ugly
}

\author{
By Eric Hollander, MD
}

This month's issue deals with new technology that has the potential not only to advance human health but also to create new and unexpected forms of human suffering.

DNA microarrays have tremendous promise for the development of personalized medicine, allowing physicians to select specific treatments to maximize therapeutic efficacy and to minimize side effects, based on an individual's unique genetic profile. They allow for the simultaneous testing of thousands of DNA sequences, and the AmpliChip CYP450 test employs this technology for cytochrome P450 (CYP) 2D6 and CYP2C19 genotyping. Isoenzymes coded by these genes metabolize many prescribed drugs. Jose de Leon, MD, and colleagues identified these alleles and phenotypes in 4,532 psychiatric patients. The prevalence of CYP2D6 poor metabolizers was $7.6 \%(8.2 \%$ in Caucasians, $1.8 \%$ in the African Americans). The prevalence of CYP2D6 ultrarapid metabolizers was $1.5 \%(1.5 \%$ in Caucasians, $2.0 \%$ in African Americans). The prevalence of CYP2C19 poor metabolizers was $2.0 \%(2.2 \%$ in Caucasians, $4.0 \%$ in African Americans). De Leon and colleagues propose a numeric system for expression of CYP2D6 and CYP2C19 enzyme activity to aid clinicians in determining treatment strategy for patients receiving therapeutics that are metabolized by the CYP2D6 or CYP2C19 gene products. DNA technology is rapidly becoming more powerful, and its costs are rapidly decreasing. However, the practical impact of such technology has been relatively limited to date. One exception is the gene testing for cytochrome isoenzymes involved in metabolizing drugs, which does have some impact in everyday clinical practice. This article is helpful in determining how common slow and rapid metabolizers of CYP gene products are, and how to use this information in determining treatment options.

Alan D. Feiger, MD, and colleagues compared the efficacy and safety of desvenlafaxine succinate versus placebo in treating major depressive disorder (MDD) in a randomized, double-blind study of adult patients with MDD. In this study, the primary analysis did not show significant differences between desvenlafaxine and placebo; discontinuations due to AEs associated with the desvenlafaxine dose range may have contributed to the lack of statistical separation. Discontinuation rates due to adverse events (AEs) were $12 \%$ and $3 \%$ for desvenlafaxine and placebo, respectively. On secondary measures, differences in week 8 observed cases and at the final evaluation were significant for the primary measures. The most frequently reported AE associated with desvenlafaxine was nausea ( $36 \%$ vs $9 \%)$. Thus, in this single trial, avoiding variations in first pass liver metabolism did not eliminate the side effects of the active metabolite.

Dyke-Davidoff-Masson syndrome, or cerebral hemiatrophy, is a pre- or perinatally acquired entity and is characterized by predominantly neurologic symptoms, such as seizures, facial asymmetry, contralateral hemiplegia, and mental retardation. Benedikt Amann, MD, PhD, and colleagues report the first case of left cerebral hemiatrophy and a late onset of treatment-resistant schizoaffective disorder after a stressful life event. The patient finally responded well to clozapine. The clinical history and results from structural neuroimaging are highlighted to discuss the possible developmental bias for psychotic disorders. Thus, psychotic symptoms may occur within the context of a complex neurologic presentation and having a unique developmental trajectory.

New technologies do have the potential to advance human health as well as to lead to unexpected forms of human suffering. DNA microarrays do have tremendous promise for the development of personalized medicine.

Finally, I would like to express my profound thanks to all of our peer reviewers, listed on the following page. The hard work of these talented and dedicated individuals has allowed the journal to experience a dramatic improvement not only in impact factor (3.409 for Psychiatry and 2.746 for Clinical Neurology), but also in readership interest. CNS

Dr. Hollander is the editor of this journal and director of the Institute of Clinical Neuroscience in New York City. 


\section{We would like to thank the following peer reviewers who contributed to CNS Spectrums in 2008:}

Lenard Adler, MD

Kevin Antshel, PhD

Donna L. Antonucci, MD, FAAP

Birgit Assmann, PhD

Alireza Atri, MD, PhD

Roger Baird, MD, PhD

Thomas A. Ban, MD, FRCP

David Baron, MSEd, DO

George Bartzokis, MD

Randall Bateman, MD

Cesario Bellantuono, MD

Peter Mclaren Black, MD

Carlos Blanco, MD, PhD

Charles L. Bowden, MD

Andrew E. Budson, MD

John Calamari, $\mathrm{PhD}$

Brendan T. Carroll, MD

Franca Centorrino, MD

Jack Chen, PharmD

Joe Clem, MD

Andreas Conca, MD

Bruno Conti, PhD

Josep Dalmau, MD, PhD

Pinhas Dannon, MD

Marilyn Davies, PhD, MSN, RN

Jose de Leon, MD

Bernardo Dell'Osso, MD

Brad Dickerson, MD

Ted Dinan, MD, PhD

Andrew H. Evans, FRACP

Omar Fattal, MD

Giovanni Andrea Fava, MD

Ygor Ferrao, MD, MSc, PhD

Maria Luísa Figueira, MD, PhD

Massimiliano Filosto, MD, PhD

Leonardo F. Fontenelle, MD, PhD

Adriana Foster, MD

Thomas Frazier, $\mathrm{PhD}$

Elbert Geuze, PhD

David L. Ginsberg, MD

Michael Gitlin, MD

John Goethe, MD

Joseph F. Goldberg, MD
Guy Goodwin, DPhil, FMedSci, FRCPsych

Marco A. Grados, MD, MPH

George T. Grossberg, MD

Ruth Gross-Isseroff, DSc

David Gurwitz, PhD

Philip D. Harvey, PhD

Robert A. Hauser, MD

Haggai Hermesh, MD

E. Hogervorst, PhD

Arshad Husain, MD

Charles J. Ippolito, MD

Colleen Jackson-Cook, PhD, FACMG

Jacques Jaeken, MD, PhD

Ari Kalechstein, PhD

David Kemp, MD

Gary J. Kennedy, MD

Scott H. Kollins, PhD

Athanasios Koukopoulos, MD

Roger Kurlan, MD

Athanasios Kyritsis, MD

Andrew F. Leuchter, MD

Mark Lew, MD

Paul Links, MD

Chia-Yih Liu, MD

Phillip Maiden, MD

Donatella Marazziti, MD

Isaac Marks, MD

J.P. McEvoy, MD

Aaron McMurtray, MD

Herbert Meltzer, MD

Samantha Metzler-Brody, MD

Evan Murray, MD

David J. Muzina, MD

Sharon Naismith, BA, DPsych

Humberto Nicolini, MD, PhD

Martin Offenbaecher, MD

Maria A. Oquendo, MD

Stefano Pallanti, MD, PhD

Ilenia Pampaloni, MD

Andreas Papadopoulos, MSc

Joel Paris, MD
James C. Patterson II, MD, PhD

Giulio Perugi, MD

Eric Peselow, MD

Harrison G. Pope, Jr., MD

Anton Porsteinsson, MD

Thomas J. Raedler, MD

J. Russell Ramsay, PhD

Murali Rao, MD, DFAPA, FAPM

James H. Ray, PhD

Nancy S. Redeker, PhD, RN

John Reid, DPhil, BSc, BM, MRCP

Zoltán Rihmer, MD, PhD, DSc

Joe Sam Robinson, Jr., MD

Albina Rodrigues Torres, MD,

PhD

Leonardo Rodriguez, MD

Ramon Rodriguez, MD

Timothy A. Roehrs, PhD

Martin J. Sadowski, MD, PhD

Paul Sandor, MD, FRCPC

David Sarwer, PhD

Marcelo Schmitz, MD, PhD

Robert Schwarcz, PhD

Lauren C. Seeberger, MD

Mark Stacy, MD

Daniel Stewart, MD

Eric Storch, PhD

Tracy Stroud, DO

Russell H. Swerdlow, MD

Hermano Tavares, MD, PhD

Antonio L. Teixeira, MD, PhD

Per Hove Thomsen, MD

Magda Tsolaki, MD, PhD

Rasit Tukel, MD

Michael Van Ameringen, MD, FRCPC

Oriana Vesga, MD

William J. Weiner, MD

Abraham Weizman, MD

David Williams, PhD

Sue Wilson, PhD

Thomas N. Wise, MD 